\begin{abstract}
論 文
固有值・固有べクトルによる区分的 2 次線形システムの 安定条件*

村松 鋭一†・渡部 慶二†‡

\section{Stability Condition of Piecewise Linear Second-Order Systems via Eigenvalues and Eigenvectors*}

\author{
Eiichi Muramatsu ${ }^{\dagger}$ and Keiji Watanabe ${ }^{\dagger \ddagger}$
}

\begin{abstract}
This paper considers stability of piecewise linear second-order systems. We analyze the trajectory of the systems by using eigenvalues and eigenvectors of coefficient matrices of subsystems. For the case where the coefficient matrices have complex eigenvalues, we present the necessary and sufficient condition for the piecewise linear systems to be stable.
\end{abstract}

\section{1.はじめに}

微分方程式で記述される連続ダイナミクスと, 論理 条件による切替のような離散ダイナミクスの混在す るハイブリッドシステムは，近年さまざまなアプロー チによって研究されている. 中でも, $\dot{x}(t)=A_{i} x(t)$ の 係数行列 $A_{i}(i=1, \cdots, N)$ が切り替わるシステムの安 定性は最も基本的な問題の一つであり，参考文献 $[1$, 2]などで研究動向が解説されている。この種の問題に対 する一つのアプローチとして, Lyapunov 関数を用いた 安定性解析が考えられるが，多くの場合安定となるため の十分条件しか得られない [3].

本論文では安定となるための必要十分条件を示すため, 解軌道を支配する各サブシステムの固有值を用いた安定 性解析を行う。このようなアプローチによる研究として, 参考文献 [4-7] が挙げられる.

参考文献 [4] では, $A_{i}(i=1, \cdots, N)$ を互いに交換則が 成り立つクラスに限定したうえで，ある定められた時間 にしたがって $A_{i}$ に切替が生じるシステムの安定性が解

* 原稿受付 2004 年 7 月 7 日

$\dagger$ 山形大学 工学部 Faculty of Engineering, Yamagata University; 4-3-16 Jonan, Yonezawa city, Yamagata $992-8510$, JAPAN

‡理化学研究所 バイオミメティックコントロール研究セン ター Bio-Mimetic Control Research Center, The Institute of Physical and Chemical Research (RIKEN); 2271130, Anagahora, Shimoshidami, Moriyama-ku, Nagoya, Aichi 463-0003, JAPAN

Key Words: hybrid system, piecewise linear system, stability condition, eigenvalue, eigenvector.
析され， $A_{i}$ の固有值を用いた安定条件が与えられてい る. 参考文献 [5-7] においては $x(t)$ のとる值によって $A_{i}$ に切替が生じる区分的線形システムが扱われ，固有值に 着目した安定性解析が行われている. 参考文献 [5]では, サブシステムの数を二つとした 2 モードの区分的線形シ ステムが扱われており, サブシステムの次数が 2 次の場 合に対しては必要十分条件を, $n$ 次の場合では, 必要条 件と十分条件を示している. 参考文献 $[6]$ では, サブシス テムの次数を 2 次と限定するが個数は二つ以上とした多 モード区分的 2 次線形システムが取り扱われている。こ こでは, 解軌道の特性が $A_{i}$ の固有值との関連からいく つかのクラスに分類され, それぞれの場合に応じて安定 となるための必要十分条件が示されている．参考文献 $[5$, 6] の結果は参考文献 [7]でもまとめられている.

本論文では参考文献 [6] で扱われた多モード区分的 2 次線形システムのうち, $A_{i}(i=1, \cdots, N)$ の固有值が複 素数である場合の安定条件を, 参考文献 [6] で示されて いる条件とは異なった形式で示す。 その形式とは $A_{i}$ の 固有値が陽に現れたものである。

区分的 2 次線形システムの安定性には，切替の境界 を定める直線と, 各サブシステムの解軌道の曲線形状と の位置関係が関わってくる. その解軌道の曲線形状は, $A_{i}$ の固有值だけでなく, 固有べクトルも関連して決ま る.そこで本論文では, 固有值だけでなく固有べクト ルにも着目して安定性解析を行う。そして, 多モード区 分的 2 次線形システムが安定となる必要十分条件を $A_{i}$ $(i=1, \cdots, N)$ の固有值・固有べクトルを用いた式で示す.

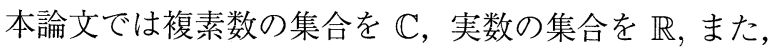


正の実数の集合を $\mathbb{R}_{+}$と表す.

\section{2. 問題設定}

\section{1 多モード区分的 2 次線形システム}

本論文では多モード区分的 2 次線形システムをつぎの ように定義する。

$$
\dot{x}(t)=\left\{\begin{array}{cc}
A_{1} x(t), & \text { if } x(t) \in \mathcal{S}_{1} \\
A_{2} x(t), & \text { if } x(t) \in \mathcal{S}_{2} \\
\vdots & \\
A_{N} x(t), & \text { if } x(t) \in \mathcal{S}_{N}
\end{array}\right.
$$

ただし， $x(t) \in \mathbb{R}^{2}, A_{i} \in \mathbb{R}^{2 \times 2}$ である. $\mathcal{S}_{i}(i=1, \cdots, N)$ は，Fig. 1に見られるような原点を始点とする 0 でない 定数べクトル $v_{i} \in \mathbb{R}^{2}(i=1, \cdots, N)$ を用いて,

$$
\mathcal{S}_{i}=\left\{c_{1} v_{i}+c_{2} v_{i+1} \in \mathbb{R}^{2} \mid c_{1}, c_{2} \text { は非負の実数 }\right\}
$$

と表される領域である。ただし， $v_{i}$ における添え字 $i$ の 順序付けは Fig.1 のような時計回りの順序にしたがうと する. $(2)$ 式より $\mathcal{S}_{i}$ はFig.1のように $v_{i}$ および $v_{i+1}$ で 方向を示される半直線を境界とする扇型の領域を表す.

$v_{i}$ と $v_{i+1}$ のなす角は $\pi[\mathrm{rad}]$ 以下とする.もし Fig. 2 内の左図のように $\pi$ よりも大きな角をもつ領域がある場 合には， $v_{i}$ と $v_{i^{\prime}}$ ，および $v_{i^{\prime}}$ と $v_{i+1}$ のなす角が $\pi$ より 小さくなるような $v_{i^{\prime}}$ を新たに追加して, $\mathcal{S}_{i}(i=1, \cdots, N)$ を定義し直すとする (Fig. 2 内の右図の場合， $v_{2}$ を追加 している.この場合， $A_{1}=A_{2}$ となる）.

本論文では，ある $i$ に対する $\dot{x}(t)=A_{i} x(t)$ を「サブ システム」, サブシステム $\dot{x}(t)=A_{i} x(t)$ に対する $x(t)$ の軌道を「サブシステムの軌道」, $A_{i}$ の固有值を「サブ

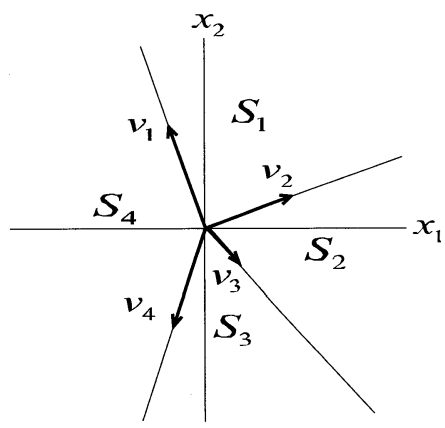

Fig. 1 Region of $\mathcal{S}_{i}$

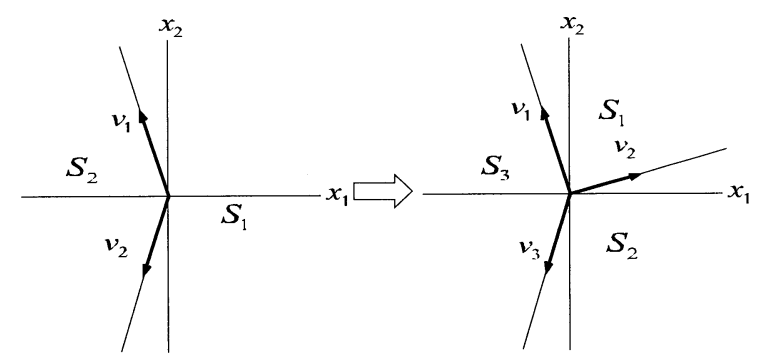

Fig. 2 Redifinition of $\mathcal{S}_{i}$
システムの固有值」とよぶことにする．また，(1) 式の 多モード区分的 2 次線形システムの解軌道 $x(t)$ が任意 の初期状態から原点に漸近するとき, $(1)$ 式のシステム は安定である」という。

（注意 1）参考文献 [6] での領域の分割は, 定数べク トル $C_{\mathcal{I}} \in \mathbb{R}^{1 \times 2}(\mathcal{I}=1, \cdots r)$ で定められる $r$ 本の直線 $C_{\mathcal{I}} x=0$ を用いて, $2^{r}$ 個の領域を定義するものである. このような領域分割は本論文における $v_{i}$ と $A_{i}$ を適当 に定めればFig. 1 のような $\mathcal{S}_{i}$ を用いた分割として可能 である。また，本論文で用いている領域の分割は参考文 献 [6]での $C_{\mathcal{I}}(\mathcal{I}=1, \cdots, r)$ と $A_{i}\left(i=1, \cdots, 2^{r}\right)$ を適当 に定めても可能である。したがって，領域の分割に関し ては本論文と参考文献 [6] は同じ自由度をもっている。

\section{2 行列 $A_{i}$ に対する仮定}

本論文ではつぎの仮定 1,2 をおく.

【仮定 1】 $A_{i}(i=1, \cdots, N)$ は複素数の固有值

$$
\alpha_{i} \pm j \beta_{i}, \quad \alpha_{i}, \beta_{i} \in \mathbb{R}, \quad \beta_{i}>0
$$

をもつとする。

この仮定のもとでは, 固有值 $\alpha_{i}+j \beta_{i}, \alpha_{i}-j \beta_{i}(i=$ $1, \cdots, N)$ に対応する固有べクトルはそれぞれ，

$$
\left[\begin{array}{c}
1 \\
a_{i}+j b_{i}
\end{array}\right],\left[\begin{array}{c}
1 \\
a_{i}-j b_{i}
\end{array}\right], a_{i}, b_{i} \in \mathbb{R}, \quad b_{i} \neq 0
$$

と表わすことができる（付録 1 . 参照）。

【仮定 2】 $b_{i}>0, i=1, \cdots, N$

とする。

$x(t)=\left[\begin{array}{ll}x_{1}(t) & x_{2}(t)\end{array}\right]^{\mathrm{T}}$ とするとき， $x_{1}$ を横軸に， $x_{2}$ を縦軸にとった平面を「 $x$ 平面」とよぶことにする. 仮 定 1 より， $x$ 平面におけるサブシステムの軌道は Fig. 3 のように渦状の軌道の一部となる。この渦の回転方向は $\beta_{i} / b_{i}$ が正の場合に時計回りになる (付録 2. 参照) . (3) 式で $\beta_{i}>0$ としているので，(5) 式よりすべてのサブシ ステムの軌道の回転方向は時計回りとなる。これに反し て，もし $b_{i-1}>0$ で $b_{i}<0$ とすると, $\mathcal{S}_{i-1}$ と $\mathcal{S}_{i}$ の境 界に执いて逆回転の軌道が交差してスライディングモー ドが発生する．仮定 2 はそのような場合を考察から除外 することを意味する。

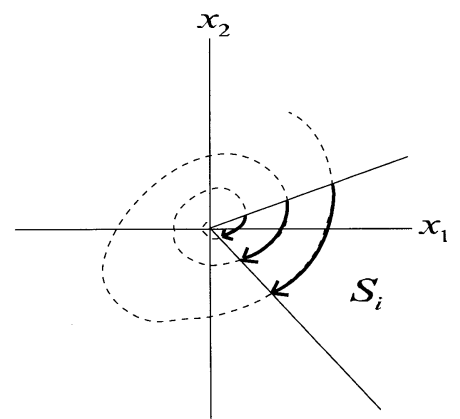

Fig. 3 Trajectory of $x(t)$ of a subsystem 


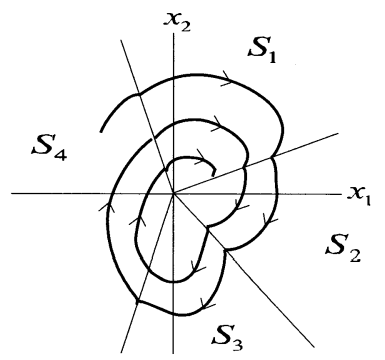

Fig. 4 Trajectory of $x(t)$ of a piecewise linear system

仮定 1, 2 より (1) 式の軌道 $x(t)$ は Fig. 4 のように $\mathcal{S}_{1} \cdots \mathcal{S}_{N}$ の各領域を遷移し, その遷移は周期的に繰り 返される（領域 $\mathcal{S}_{i}$ から $\mathcal{S}_{i+1}$ へ，そして $\mathcal{S}_{N}$ のつぎは $\mathcal{S}_{1}$ へ遷移する).

（注意 2）参考文献 $[6,7]$ では本論文の仮定 1,2 の ような仮定は設けず, 軌道の特性を分類して, 各場合 における安定条件を示している。本論文での仮定 1 , 2 が成り立つ場合の安定条件も参考文献 $[6,7]$ で示され ているが，それは $\prod_{i=1}^{2^{r}}\left\|e^{A_{i} \tau_{i}} x_{i}\right\|<1$ という $A_{i}$ の行 列指数関数を含む形式であり, 固有值が安定条件に陽 に現れていない。そのため, 安定性と固有值の関係を 式から読み取ることができない。本論文ではこれとは 異なる形式として, 行列を含まず， $A_{i}$ の固有値が陽に 現れるような安定条件の式を示す。そのために, 本論 文では固有值だけでなく, 固有べクトルにも着目して (その理由は次節で述べる) 解析を行う。この固有べク トルを用いた問題に対するアプローチは参考文献 [57]には見られない本論文の特徴である.

なお，仮定 2 で述べた符号がすべて負の場合には， $x(t)$ の回転方向が逆向きになるだけなので, 正の場合と 同様な手法で安定条件を導出できる.

\section{3 安定性を決めるパラメータ}

区分的 2 次線形システムの安定性の特徵が現れる例 として Fig. 5 で表されるものがある [1]. Fig. 5 内の左 上図は $\dot{x}(t)=A_{1} x(t)$ にしたがう $x(t)$ の軌道, 右上図 は $\dot{x}(t)=A_{2} x(t)$ にしたがう $x(t)$ の軌道である.ここ でFig. 5 内の左中図のように,

$$
v_{1}=\left[\begin{array}{l}
0 \\
1
\end{array}\right], v_{2}=\left[\begin{array}{l}
1 \\
0
\end{array}\right], v_{3}=\left[\begin{array}{c}
0 \\
-1
\end{array}\right], v_{4}=\left[\begin{array}{c}
-1 \\
0
\end{array}\right]
$$

によって領域 $\mathcal{S}_{i}(i=1, \cdots, 4)$ が定義され，

$$
A_{1}=A_{3}, \quad A_{2}=A_{4}
$$

が成り立つ場合を考える。このとき $x(t)$ は Fig. 5 内の 右中図のような軌道を描いて原点に漸近する。一方，同 ビサブシステムのもとで Fig. 5 内の左下図のような領域 を設定すると $x(t)$ は右下の図のように発散する。

この例は, 区分的 2 次線形システムの安定性が各サ ブシステムの固有值だけでは判別できず，各サブシステ ムの軌道の曲線形状と領域の分割の仕方にも依存して
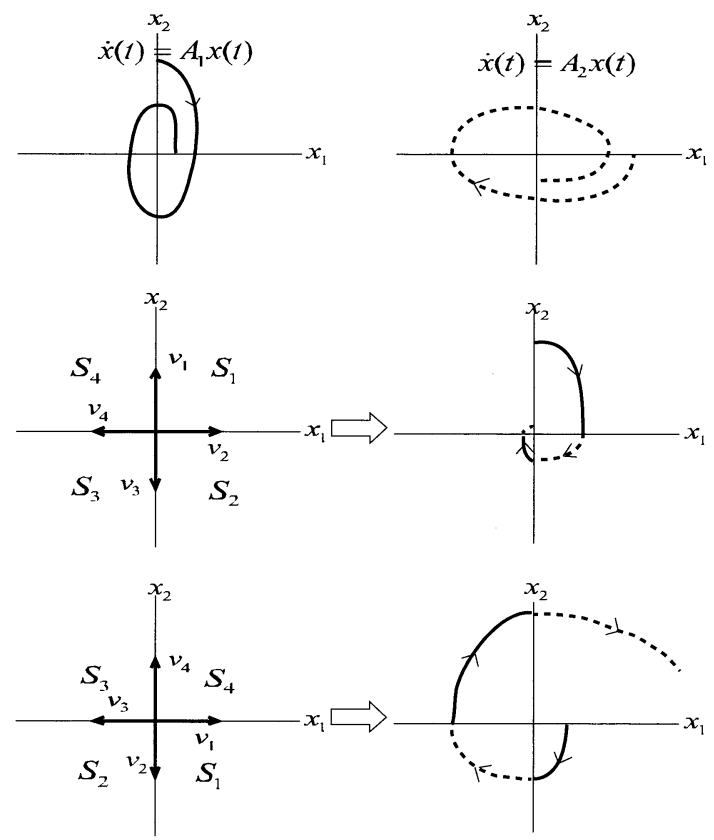

Fig. 5 Relation between subsystems and piecewise linear system

いることを表している. Fig. 5 内に示されるようなサブ システムの軌道の曲線形状は， $A_{i}$ の固有值とともに固 有べクトルにも依存して決まる。そこで本論文では，サ ブシステムの軌道の曲線形状を決めるパラメータとし て, 各 $A_{i}$ の固有值と固有ベクトルを表す $\alpha_{i}, \beta_{i}, a_{i}, b_{i}$ $(i=1, \cdots, N)$ を採用する.

(1) 式のシステムの安定性は, これらのパラメータ と, 切替の境界となる直線の方向を示すべクトル $v_{i}$ $(i=1, \cdots, N)$ の関係から決まると考えられる. 本論文で は，(1) 式のシステムが安定となる必要十分条件を $\alpha_{i}$, $\beta_{i}, a_{i}, b_{i}, v_{i}(i=1, \cdots, N)$ を用いて示す.

\section{3. 変数変換}

本論文での安定性解析に有効な変数变換について述べ ておく.

$A_{i}$ の固有值 ·固有ベクトルの関係より, (4) 式の固有 ベクトルを並べた行列

$$
\tilde{T}_{i}=\left[\begin{array}{cc}
1 & 1 \\
a_{i}+j b_{i} & a_{i}-j b_{i}
\end{array}\right]
$$

に対して，

$$
\tilde{T}_{i}^{-1} A_{i} \tilde{T}_{i}=\left[\begin{array}{cc}
\alpha_{i}+j \beta_{i} & 0 \\
0 & \alpha_{i}-j \beta_{i}
\end{array}\right]
$$

が成り立つ（本節では添え字 $i$ は $i=1, \cdots, N$ のいずれ かを表すとする)。

$$
T=\left[\begin{array}{cc}
1 & -j \\
1 & j
\end{array}\right]
$$

として，(9)式の両辺に左から $T^{-1}$ ，右から $T$ をか 
けると，

$$
T_{i}^{-1} A_{i} T_{i}=\Gamma_{i}
$$

が得られる。ただし，

$$
T_{i} \triangleq \tilde{T}_{i} T=\left[\begin{array}{cc}
2 & 0 \\
2 a_{i} & 2 b_{i}
\end{array}\right]
$$

であり，

$$
\begin{aligned}
\Gamma_{i} & \triangleq T^{-1}\left[\begin{array}{cc}
\alpha_{i}+j \beta_{i} & 0 \\
0 & \alpha_{i}-j \beta_{i}
\end{array}\right] T \\
& =\left[\begin{array}{cc}
\alpha_{i} & \beta_{i} \\
-\beta_{i} & \alpha_{i}
\end{array}\right]
\end{aligned}
$$

である. (1) 式での第 $i$ 番目のサブシステム $\dot{x}(t)=A_{i} x(t)$ に対して，(12)式の $T_{i}$ を用いて

$$
x(t)=T_{i} \eta_{i}(t)
$$

という変数変換を行えば, $(11)$ 式より変数 $\eta_{i}(t)$ は,

$$
\dot{\eta}_{i}(t)=\Gamma_{i} \eta_{i}(t)
$$

という方程式にしたがう. (13) 式で表される行列 $\Gamma_{i} に$ 対する行列指数関数は,

$$
e^{\Gamma_{i} t}=e^{\alpha_{i} t}\left[\begin{array}{cc}
\cos \beta_{i} t & \sin \beta_{i} t \\
-\sin \beta_{i} t & \cos \beta_{i} t
\end{array}\right]
$$

と表される [8].これを用いれば，初期值 $\eta_{i}(0)$ に対する $(15)$ 式の $\eta_{i}(t)$ の軌道は

$$
\begin{aligned}
\eta_{i}(t) & =e^{\Gamma_{i} t} \eta_{i}(0) \\
& =e^{\alpha_{i} t}\left[\begin{array}{cc}
\cos \beta_{i} t & \sin \beta_{i} t \\
-\sin \beta_{i} t & \cos \beta_{i} t
\end{array}\right] \eta_{i}(0)
\end{aligned}
$$

と表される。

$\eta_{i}(t)=\left[\begin{array}{ll}\eta_{i 1}(t) & \eta_{i 2}(t)\end{array}\right]$ とするとき, $\eta_{i 1}$ を横軸に, $\eta_{i 2}$ を縦軸にとった平面を「 $\eta_{i}$ 平面」とよぶことにする. (17) 式は, その平面でのベクトル $\eta_{i}(0)$ を原点からの距 離を変えつつ回転を加える変換とみなすことができ，べ クトル $\eta_{i}(t)$ に関するつぎの性質 $(\mathrm{C} 1),(\mathrm{C} 2)$ を述べるこ とができる。

(C1) $\eta_{i}(t)$ の原点からの距離は初期值 $\eta_{i}(0)$ に対して $e^{\alpha_{i} t}$ 倍される.すなわち

$$
\frac{\left\|\eta_{i}(t)\right\|}{\left\|\eta_{i}(0)\right\|}=e^{\alpha_{i} t}
$$

である．ただし，\|・\|はベクトルのユークリッドノ ルムを表す。

(C2) $\eta_{i}$ 平面におけるべクトル $\eta_{i}(t)$ の原点を中心とす る回転の角速度の大きさは $\beta_{i}$ である。

\section{4. 区分的 2 次線形システムの安定条件}

この節では $(1)$ 式のシステムの安定条件を示すが，ま ずはそのための補題を述べる，なお，以降の式の展開の ため, 2 次元ベクトル $v_{i}(i=1, \cdots, N)$ を

$$
v_{i}=\left[\begin{array}{l}
v_{i, 1} \\
v_{i, 2}
\end{array}\right]
$$

と表すとする.

【補題 1】(1) 式のシステムの軌道 $x(t)$ が, 領域 $\mathcal{S}_{i-1}$ から $\mathcal{S}_{i}$ へ，そして $\mathcal{S}_{i+1}$ へ遷移するとする (Fig. 6 の左) とき, $x(t)$ が領域 $\mathcal{S}_{i}$ に滞在する時間 $t_{i}$ は,

$$
\begin{gathered}
t_{i}=\frac{1}{\beta_{i}} \cos ^{-1}\left\{\frac{1}{\sqrt{\left(b_{i} v_{i, 1}\right)^{2}+\left(v_{i, 2}-a_{i} v_{i, 1}\right)^{2}}}\right. \\
\left.\frac{b_{i}^{2} v_{i, 1} v_{i+1,1}+\left(v_{i, 2}-a_{i} v_{i, 1}\right)\left(v_{i+1,2}-a_{i} v_{i+1,1}\right)}{\sqrt{\left(b_{i} v_{i+1,1}\right)^{2}+\left(v_{i+1,2}-a_{i} v_{i+1,1}\right)^{2}}}\right\}
\end{gathered}
$$

と表される。ただし,$i=N$ のときの $i+1$ は 1 を表す とする。

（証明）時間 $t_{i}$ の間の $x(t)$ の軌道は Fig. 6 内の左図 で表され，これを $(14)$ 式で $\eta_{i}$ 平面に変換した軌道は Fig. 6 内の右図となる.これより, 軌道 $\eta_{i}(t)$ が $T_{i} v_{i}$ で 示される直線を通過してから， $T_{i} v_{i+1}$ で示される直線を 通過するまでの時間が $t_{i}$ となる. この $\eta_{i}(t)$ の回転角の 大きさを $\theta$ とすると（Fig. 6 内の右図参照）, 前節で述 べた性質 (C2)より,

$$
\theta=\beta_{i} t_{i}
$$

が成り立つ.また， 2.1 で述べたように $v_{i}$ と $v_{i+1}$ のな す角が $\pi$ 以下であることから， $\theta$ もまた $\pi$ 以下となり，

$$
\theta=\cos ^{-1} \frac{\left(T_{i}^{-1} v_{i}\right) \bullet\left(T_{i}^{-1} v_{i+1}\right)}{\left\|T_{i}^{-1} v_{i}\right\| \cdot\left\|T_{i}^{-1} v_{i+1}\right\|}
$$

と表せる．ただし，・はつのべクトルの内積であり， 上式の $\cos ^{-1}$ は $0<\theta \leq \pi$ の值をとる. (21) 式と (22) 式より,

$$
t_{i}=\frac{1}{\beta_{i}} \cos ^{-1} \frac{\left(T_{i}^{-1} v_{i}\right) \bullet\left(T_{i}^{-1} v_{i+1}\right)}{\left\|T_{i}^{-1} v_{i}\right\| \cdot\left\|T_{i}^{-1} v_{i+1}\right\|}
$$

となり，この式に (12) 式と (19) 式を代入して計算する と $(20)$ 式になる.

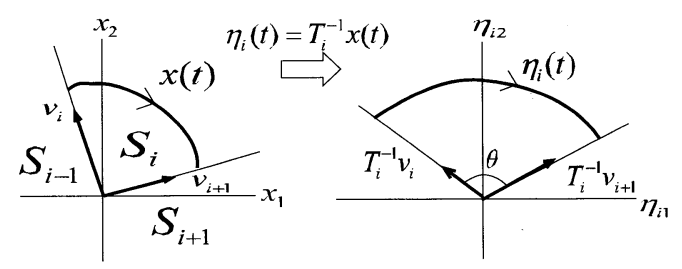

Fig. 6 Trajectories of $x(t)$ and $\eta_{i}(t)$ in dwell time $t_{i}$ 
(20) 式より, 時間 $t_{i}$ は $\beta_{i}, a_{i}, b_{i}, v_{i}$ から決まる定数 となることがわかる.

区分的 2 次線形システムの安定条件としてつぎの定理 が導かれる.

【定理 1】仮定 1，2 が成り立つとする。(1)式のシ ステムが安定であるための必要十分条件は

$$
\sum_{i=1}^{N}\left\{\alpha_{i} t_{i}+\frac{1}{2} \log \frac{\left(b_{i} v_{i, 1}\right)^{2}+\left(v_{i, 2}-a_{i} v_{i, 1}\right)^{2}}{\left(b_{i-1} v_{i, 1}\right)^{2}+\left(v_{i, 2}-a_{i-1} v_{i, 1}\right)^{2}}\right\}<0
$$

が成り立つことである。ただし， $t_{i}$ は $(20)$ 式で表され る.また，(24) 式において， $i=1$ のときの $i-1$ は $N$ を表すとする。

（証明）初期值 $x(0)$ が領域 $\mathcal{S}_{N}$ にあるとする。仮定 1, 2 より $x(t)$ の軌道は Fig. 4 のようになる. 時刻 $t$ に おいて軌道 $x(t)$ が領域 $\mathcal{S}_{m}(m$ は $1, \cdots, N$ のいずれ か）にあるとすれば，

$$
\begin{aligned}
x(t)= & e^{A_{m} \bar{t}_{m}} \cdots e^{A_{1} t_{1}}\left(e^{A_{N} t_{N}} \cdots e^{A_{1} t_{1}}\right) \\
& \cdots\left(e^{A_{N} t_{N}} \cdots e^{A_{1} t_{1}}\right) e^{A_{N} \bar{t}_{N}} x(0)
\end{aligned}
$$

と表される。ただし，上式右辺 2 行目に扔ける最初の $\left\lceil\cdots 」 は\left(e^{A_{N} t_{N}} \cdots e^{A_{1} t_{1}}\right)\right.$ の繰返しを表す。また, $\bar{t}_{N}$ は 軌道 $x(t)$ が初期值 $x(0)$ から $\mathcal{S}_{\mathcal{N}}$ の境界へ至るまでの 時間であり, $\bar{t}_{m}$ は時刻 $t$ 直近での $x(t)$ の $\mathcal{S}_{m}$ に扔け る滞在時間である。(11)式より，

$$
e^{A_{i} t_{i}}=T_{i} e^{\Gamma_{i} t_{i}} T_{i}^{-1}
$$

と書けるので，これを $(25)$ 式に代入すると，

$$
\begin{aligned}
x(t)= & e^{A_{m} \bar{t}_{m}} \cdots e^{A_{1} t_{1}}\left(T_{N} e^{\Gamma_{N} t_{N}} T_{N}^{-1} \cdots T_{1} e^{\Gamma_{1} t_{1}} T_{1}^{-1}\right) \\
& \cdots\left(T_{N} e^{\Gamma_{N} t_{N}} T_{N}^{-1} \cdots T_{1} e^{\Gamma_{1} t_{1}} T_{1}^{-1}\right) \\
& \cdot T_{N} e^{\Gamma_{N} \bar{t}_{N}} T_{N}^{-1} x(0) \\
= & e^{A_{m} \bar{t}_{m}} \cdots e^{A_{1} t_{1}} T_{N}\left(e^{\Gamma_{N} t_{N}} T_{N}^{-1} T_{N-1} \cdots\right. \\
& \left.e^{\Gamma_{1} t_{1}} T_{1}^{-1} T_{N}\right) \cdots\left(e^{\Gamma_{N} t_{N}} T_{N}^{-1} T_{N-1} \cdots\right. \\
& \left.e^{\Gamma_{1} t_{1}} T_{1}^{-1} T_{N}\right) \cdot e^{\Gamma_{N} \bar{t}_{N}} T_{N}^{-1} x(0) \\
= & M \Phi \cdots \Phi \cdot \Phi \cdot \tilde{v}_{N}
\end{aligned}
$$

を得る。ただし，

$$
\begin{aligned}
M & \triangleq e^{A_{m} \bar{t}_{m}} \cdots e^{A_{1} t_{1}} T_{N} \\
\Phi & \triangleq e^{\Gamma_{N} t_{N}} T_{N}^{-1} T_{N-1} \cdots e^{\Gamma_{1} t_{1}} T_{1}^{-1} T_{N} \\
\tilde{v}_{N} & \triangleq e^{\Gamma_{N} \bar{t}_{N}} T_{N}^{-1} x(0)
\end{aligned}
$$

である. (30)式のべクトル $\tilde{v}_{N}$ は

$$
\begin{aligned}
\tilde{v}_{N} & =e^{\Gamma_{N} \bar{t}_{N}} \eta_{N}(0) \\
& =c T_{N}^{-1} v_{1}, \quad c \in \mathbb{R}_{+}
\end{aligned}
$$

と書くことができる（Fig.7）。すなわち，ベクトル $\tilde{v}_{N}$ は $T_{N}^{-1} v_{1}$ 方向を向いている.

$x(t)$ が原点へ漸近するかどうかを考察するため,

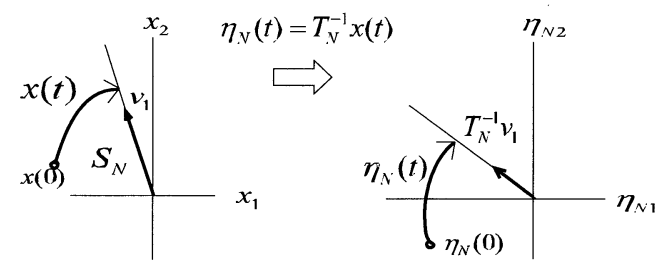

Fig. 7 Transformation from $x$-plane to $\eta_{i}$-plane

式に扮けるべクトル $\tilde{v}_{N}$ の行列 $\Phi$ による変換の繰返し の部分に注目する. (31) 式の $\tilde{v}_{N}$ を $\Phi$ で変換すると, 変 換後のベクトルはやはり $T_{N}^{-1} v_{1}$ と同じ方向を向くこと が $(29)$ 式の $\Phi$ の定義からわかる。(27) 式ではその変換 が繰り返されているので, $x(t)$ が原点へ漸近する必要十 分条件は, 行列 $\Phi$ による変換後のべクトルの長さの, 変 換前の長さに対する比（以降，ベクトルの長さの「変換 比」とよぶことにする) が 1 よりも小さいこととなる ((28) 式の $M$ による変換比は 0 より大きく, その上限 值が存在するので, $(27)$ 式で $x(t)$ の原点への漸近性を 考察するにあたっては $\Phi$ の繰返し部分のみに注目すれ ばよい)。

$\Phi$ による変換比を考察するため, (29) 式の $\Phi$ を

$$
\begin{aligned}
\Phi= & e^{\Gamma_{N} t_{N}} \cdot\left(T_{N}^{-1} T_{N-1}\right) \cdot e^{\Gamma_{N-1} t_{N-1}} \cdot\left(T_{N-1}^{-1} T_{N-2}\right) \cdots \\
& \cdots e^{\Gamma_{2} t_{2}} \cdot\left(T_{2}^{-1} T_{1}\right) \cdot e^{\Gamma_{1} t_{1}} \cdot\left(T_{1}^{-1} T_{N}\right)
\end{aligned}
$$

という $2 N$ 個の変換の積と考え, それら一つ一つの変換 によるベクトルの長さの変換比について考えていく.

まず，行列 $T_{i}^{-1} T_{i-1}$ による変換を考える．この変換 が生じるタイミングは, 軌道 $x(t)$ が $\mathcal{S}_{i-1}$ から $\mathcal{S}_{i}$ へ遷 移する瞬間, すなわち, ベクトル $x(t)$ が $v_{i}$ と同方向を 向いて

$$
x(t)=c v_{i}, \quad c \in \mathbb{R}_{+}
$$

となったときに生じる（Fig. 8 内の上図）。このとき， $\eta_{i-1}$ 平面では $\eta_{i-1}(t)$ が

$$
\eta_{i-1}(t)=T_{i-1}^{-1} x(t)=c T_{i-1}^{-1} v_{i}
$$

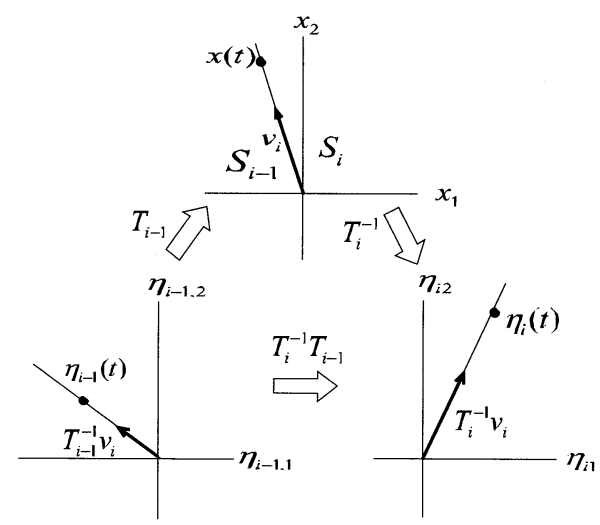

Fig. 8 Transformation by $T_{i}^{-1} T_{i-1}$ 
と表され（Fig. 8 内の左下図）， $\eta_{i}$ 平面では $\eta_{i}(t)$ が

$$
\eta_{i}(t)=T_{i}^{-1} x(t)=c T_{i}^{-1} v_{i}
$$

と表される (Fig. 8 内の右下図). 行列 $T_{i}^{-1} T_{i-1}$ による 変換は，(34) 式のベクトルを (35) 式のベクトルへ写す 変換であり，それによるべクトルの長さの変換比は，

$$
\begin{aligned}
& \frac{\left\|\eta_{i}(t)\right\|}{\left\|\eta_{i-1}(t)\right\|}=\frac{\left\|c T_{i}^{-1} v_{i}\right\|}{\left\|c T_{i-1}^{-1} v_{i}\right\|}=\frac{\left\|T_{i}^{-1} v_{i}\right\|}{\left\|T_{i-1}^{-1} v_{i}\right\|} \\
& =\frac{\left|b_{i-1}\right|}{\left|b_{i}\right|} \cdot \frac{\sqrt{\left(b_{i} v_{i, 1}\right)^{2}+\left(v_{i, 2}-a_{i} v_{i, 1}\right)^{2}}}{\sqrt{\left(b_{i-1} v_{i, 1}\right)^{2}+\left(v_{i, 2}-a_{i-1} v_{i, 1}\right)^{2}}}
\end{aligned}
$$

と表される。ただし，(36)式の導出には(12)式，(19)式 を用いた。

つぎに，(32) 式に㧍ける $e^{\Gamma_{i} t_{i}}$ による変換について考 える.この変換は Fig. 6 内の右図で表される $\eta_{i}(t)$ の推 移を与えるものである。 これは $\eta_{i}$ 平面で $\eta_{i}(t)$ を時間 $t_{i}$ だけ推移させる変換なので, 前節の $(\mathrm{C} 1)$ に扔ける $(18)$ 式より，この変換によるべクトルの長さの変換比は $e^{\alpha_{i} t_{i}}$ と表される.

(32)式の $\Phi$ は, このような 2 種類の変換行列 $T_{i}^{-1} T_{i-1}$ と $e^{\Gamma_{i} t_{i}}$ のそれぞれ $N$ 個の積として構成されている。 し たがって, 行列 $\Phi$ の変換によるべクトルの長さの変換比 は, $i=1, \cdots, N$ に対する $(36)$ 式と $e^{\alpha_{i} t_{i}}$ の積に等しい. そして前に述べたように，この值が 1 より小さいことが 安定条件である。したがって，(1)式のシステムが安定 となるための必要十分条件は,

$$
\prod_{i=1}^{N} e^{\alpha_{i} t_{i}} \frac{\sqrt{\left(b_{i} v_{i, 1}\right)^{2}+\left(v_{i, 2}-a_{i} v_{i, 1}\right)^{2}}}{\sqrt{\left(b_{i-1} v_{i, 1}\right)^{2}+\left(v_{i, 2}-a_{i-1} v_{i, 1}\right)^{2}}}<1
$$

である（(36)式に扔ける $\left|b_{i-1}\right| /\left|b_{i}\right|$ は $N$ 個の積におい て相殺されて上式には現れない)．最後に，(37)式の両 辺の自然対数をとり，(24) 式が得られる.

なお，証明に最初に初期值 $x(0)$ が領域 $\mathcal{S}_{N}$ にあると したが, 他の領域にある場合には (25) 式〜 (32) 式に 㧍いて下付きの添え字 ${ }_{1,2}, \cdots, N$ が入れ替わる. しかし， (33) 式以降は同じ議論となり, 得られる安定条件は (24) 式と同じになる.

証明中の (37) 式左辺の

$$
\rho \triangleq \prod_{i=1}^{N} e^{\alpha_{i} t_{i}} \frac{\sqrt{\left(b_{i} v_{i, 1}\right)^{2}+\left(v_{i, 2}-a_{i} v_{i, 1}\right)^{2}}}{\sqrt{\left(b_{i-1} v_{i, 1}\right)^{2}+\left(v_{i, 2}-a_{i-1} v_{i, 1}\right)^{2}}}
$$

は, ベクトルの $\Phi$ による変換比として導出された。 こ の定数 $\rho$ を用いてつぎの補題を示すことができる（証明 は付録 3. 参照) .

【補題 2】(20)式の $t_{i}(i=1, \cdots, N)$ を用いて

$$
h \triangleq \sum_{i=1}^{N} t_{i}
$$

とする. $k$ を非負の整数とするとき, 任意の初期值に対 する (1) 式の解 $x(t)$ は

$$
x(t+k h)=\rho^{k} x(t), \quad \forall t \geq 0
$$

を満たす。

この補題を用いてつぎの定理を示すことができる（証 明は付録 4.)。

【定理 2】任意の初期值に対する $(1)$ 式の解 $x(t)$ に 対して,

$$
\gamma_{\ell} e^{-\mu t} \leq\|x(t)\| \leq \gamma_{u} e^{-\mu t}, \quad \forall t \geq 0
$$

が成り立つ。ただし，

$$
\begin{aligned}
& \mu=-\frac{1}{h} \log \rho \\
& \gamma_{u}=\sup _{t_{p} \in[0, h)}\left\|x\left(t_{p}\right)\right\| e^{\mu t_{p}} \\
& \gamma_{\ell}=\inf _{t_{p} \in[0, h)}\left\|x\left(t_{p}\right)\right\| e^{\mu t_{p}}
\end{aligned}
$$

である。

(42) 式における $\log \rho$ の值は定理 1 における (24) 式 の左辺の值と等しく, これが負のときには $\mu>0$ となる. このことと (41) 式より，(1) 式のシステムが安定である とき，それは指数安定を意味する。

定理 1 から, 区分的 2 次線形システムの安定性につ いてつぎのことがいえる.

- (20) 式, (24) 式に見られるように, 安定となる必要 十分条件は $\alpha_{i}, \beta_{i}, a_{i}, b_{i}, v_{i}(i=1, \cdots, N)$ のみを用 いて記述できる。

- 安定条件に扔ける $\alpha_{i}$ の現れ方は，(24) 式において 線形に現れているのみである。したがって, 固有べ クトルが変わらず $\alpha_{i}$ の值のみが変わるとき, $\alpha_{i}$ の 值が負で小さいほどシステムの安定度 ((24) 式の左 辺の值がどれほど小さいか）は増す。

- 安定条件に打ける $\beta_{i}$ の現れ方は，(20) 式において 逆数として現れているのみである.したがって, 固 有べクトルが変わらず $\beta_{i}$ の值のみが変わるとき, $\alpha_{i}$ の值が負. (正) の場合には $\beta_{i}$ が小さい (大きい) ほどシステムの安定度は増す。

- 安定条件は $v_{i}(i=1, \cdots, N)$ の長さには依存しない. このことは $v_{i}$ の代わりに $c_{i} v_{i}, c_{i} \in \mathbb{R}_{+}$と置き換え て (20) 式と (24) 式を計算しても, もとと同じ式に なることから確認できる。

本論文の定理 1 で示された安定条件から, 従来の研 究 $[4,5]$ で得られている安定条件をつぎのように導くこ とができる。

- $A_{i} A_{j}=A_{j} A_{i}(i \neq j)$ が成り立つとき, 各 $A_{i}$ は共 通の固有べクトルをもち, $a_{i}=a_{j}, b_{i}=b_{j}(i \neq j)$ が 成り立つ.このときの定理 1 の安定条件は, 対数の 項が 0 となることにより 


$$
\sum_{i=1}^{N} \alpha_{i} t_{i}<0
$$

と表される。これは参考文献 [4] における定理 1 で $n=2$ とした場合の安定条件と一致する。

- $N=2$ かつ $v_{1}=-v_{2}$ の場合, 2 モード区分的 2 次線 形システムとなる。 この場合, $(20)$ 式の $t_{i}(i=1,2)$ は $\pi / \beta_{i}$ となるとともに，(24) 式における対数の項 は互いに相殺するため, 定理 1 の安定条件は

$$
\frac{\alpha_{1}}{\beta_{1}}+\frac{\alpha_{2}}{\beta_{2}}<0
$$

とまとめられる。これは参考文献 [5]における定理 1 の (4) 式と一致する.

また，参考文献 [1] で例として用いられた Fig. 5 のよ うなシステムの安定条件は，定理 1 の特殊な場合として 導くことができる。(6), (7) 式によってシステムが定義 されているときには,

$$
\begin{aligned}
& \alpha_{1}=\alpha_{3}, \quad \beta_{1}=\beta_{3}, \quad a_{1}=a_{3}, \quad b_{1}=b_{3} \\
& \alpha_{2}=\alpha_{4}, \quad \beta_{2}=\beta_{4}, \quad a_{2}=a_{4}, \quad b_{2}=b_{4}
\end{aligned}
$$

と(6) 式を定理 1 の条件に代入すれば，つぎのような安 定条件が得られる。

【系 1】仮定 1，2 が成り立つとする。また，(6) 式 のベクトルで領域が分割され (7) 式が成り立つとする. このとき，(1) 式のシステムが安定であるための必要十 分条件は

$$
\begin{gathered}
\frac{\alpha_{1}}{\beta_{1}} \cos ^{-1} \frac{-a_{1}}{\sqrt{a_{1}^{2}+b_{1}^{2}}}+\frac{\alpha_{2}}{\beta_{2}} \cos ^{-1} \frac{a_{2}}{\sqrt{a_{2}^{2}+b_{2}^{2}}} \\
+\frac{1}{2} \log \frac{a_{2}^{2}+b_{2}^{2}}{a_{1}^{2}+b_{1}^{2}}<0
\end{gathered}
$$

が成り立つことである。

\section{5. 数值例}

(6) 式のベクトル $v_{i}(i=1, \cdots, 4)$ で領域 $\mathcal{S}_{i}(i=1, \cdots, 4)$ がFig. 5 内の左中図のように定義されるとする。また, (7) 式が成り立ち,

$$
A_{1}=\left[\begin{array}{cc}
\sigma & 1 \\
-\omega^{2} & \sigma
\end{array}\right], \quad A_{2}=\left[\begin{array}{cc}
1 & \pi \\
-\pi & 1
\end{array}\right]
$$

の場合 $[6,7]$ を考える.この場合, 安定条件は (47) 式で 与えられる。具体的な数值を代入するため, $A_{1}, A_{2}$ の 固有值と固有べクトルを求めると,

$$
\begin{aligned}
& \alpha_{1}=\sigma, \quad \beta_{1}=\omega, \quad a_{1}=0, \quad b_{1}=\omega \\
& \alpha_{2}=1, \quad \beta_{2}=\pi, \quad a_{2}=0, \quad b_{2}=1
\end{aligned}
$$

という值を得る。これらを(47) 式の安定条件に代入す ると,

$$
\frac{\sigma \pi}{\omega}+1+\log \frac{1}{\omega^{2}}<0
$$

となる.これは参考文献 $[6,7]$ の例題で導出されている

$$
e^{1+\frac{\sigma \pi}{\omega}}<\omega^{2}
$$

という条件と等価である.

別の例として,

$v_{1}=\left[\begin{array}{c}-1 \\ 3\end{array}\right], v_{2}=\left[\begin{array}{l}2 \\ 1\end{array}\right], v_{3}=\left[\begin{array}{c}1 \\ -1\end{array}\right], v_{4}=\left[\begin{array}{l}-1 \\ -3\end{array}\right]$

であり（Fig.1のような領域の分割で），

$$
\begin{array}{ll}
A_{1}=\left[\begin{array}{cc}
-7 & 6 \\
-12 & 5
\end{array}\right], A_{2}=\left[\begin{array}{cc}
1 & 2 \\
-4 & -3
\end{array}\right] \\
A_{3}=\left[\begin{array}{cc}
3 & 2 \\
-4 & -1
\end{array}\right], \quad A_{4}=\left[\begin{array}{cc}
1 & 1 \\
-5 & -3
\end{array}\right]
\end{array}
$$

の場合の安定性を定理 1 から判別してみる。この場合，

$$
\begin{array}{llll}
\alpha_{1}=-1, & \beta_{1}=6, & a_{1}=1, & b_{1}=1 \\
\alpha_{2}=-1, & \beta_{2}=2, & a_{2}=-1, & b_{2}=1 \\
\alpha_{3}=1, & \beta_{3}=2, & a_{3}=-1, & b_{3}=1 \\
\alpha_{4}=-1, & \beta_{4}=1, & a_{4}=-2, & b_{4}=1
\end{array}
$$

となり，これと (53) 式を，(20) 式と (24) 式の左辺に代 入して計算する。この場合， $(24)$ 式が満たされるので, (1) 式のシステムは安定と判別される. 数值計算によって $x(t)$ の軌道（初期値は $x(0)=\left[\begin{array}{ll}1 & 1\end{array}\right]^{\mathrm{T}}$ ） を求めると Fig.9 のようになり，判別どおり安定であることを確認できる.

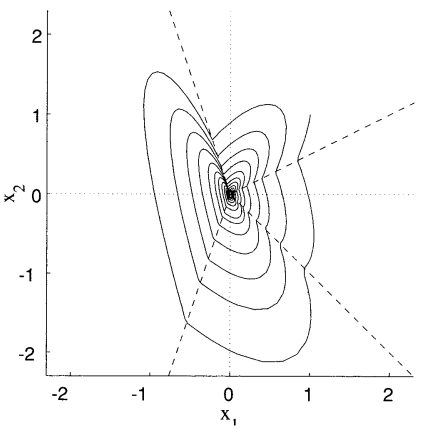

Fig. 9 Trajectory of a stable system

(54) 式の $A_{4}$ の代わりに

$$
A_{4}=\left[\begin{array}{cc}
3 & 2 \\
-10 & -5
\end{array}\right]
$$

として

$$
\alpha_{4}=-1, \quad \beta_{4}=2, \quad a_{4}=-2, \quad b_{4}=1
$$

である場合には，(24)式が満たされず，システムは不安 定と判別される. 数值計算による $x(t)$ の軌道は Fig. 10 のように発散し, 判別どおりシステムが不安定であるこ とを確認できる。 


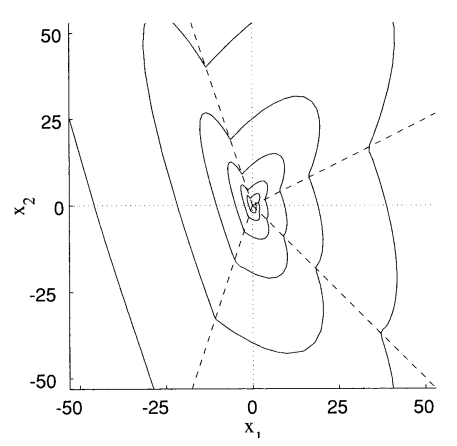

Fig. 10 Trajectory of an unstable system

\section{6. おわりに}

多モード区分的 2 次線形システムの安定解析を行い, 各サブシステムの係数行列 $A_{i}$ が複素固有值をもつ場合 について安定条件を示した，安定となる必要十分条件を 導出するため, サブシステムの軌道の曲線形状に着目し, それらを決めるパラメータとして固有值と固有ベクトル を採用した．安定性解析においては， $x(t)$ から $\eta_{i}(t)$ へ の変数変換を行い, $\eta_{i}(t)$ 平面上でのベクトルの回転と 長さの伸縮を考えることによって安定条件を導いた。 そ こで現れる変数変換行列, 回転の角速度, ベクトルの長 さの変換比などの安定条件にかかわる量のすべてが， $\alpha_{i}$, $\beta_{i}, a_{i}, b_{i}, v_{i}$ を用いて記述されたため, システムの安定 条件もそれらのパラメータのみで書き表されるものと なった。得られた安定条件には固有值が陽に現れており, 各サブシステムの固有值と区分的 2 次線形システムの安 定性の関係が明確になった。

今後の研究課題として, システムの次数を 2 次から $n$ 次へと拡張することが考元られる，それを考えるにあ たっては, 上で述べたような 2 次元べクトルの回転や伸 縮をいかに $n$ 次元へと一般化するかが問題となり, その ための数学的準備が必要となると思われる.

仮定 1,2 が満たされない場合の安定解析は参考文献 $[6$, 7]で行われているが, 固有べクトルを用いた解析は行 われていない，本論文で用いた固有べクトルのパラ メータ $a_{i}, b_{i}$ を導入することによって, 参考文献 $[6$, 7] とは別の形式での安定条件が得られる可能性があり, これについても今後の研究課題と考えている.

\section{謝辞}

本研究に関する議論に参加してくれた山形大学工学部 学生, 須藤明美さんに感謝します。

\section{参考文献}

[1] D. Liberzon and A. S. Morse: Basic problems in stability and design of switched systems; IEEE Control Systems Magazine, Vol. 19, No. 5, pp. 59-70 (1999)

[2] 山本, 増淵: ハイブリッドダイナミカルシステムの安定解 析；システム/制御／情報, Vol. 46, No. 3, pp. 120-128 (2002)
[3] 井村：ハイブリッドシステムの制御における未解決問題 ; 計測と制御, Vol. 42, No. 2, pp. 113-119 (2003)

[4] 藤澤, 村松: 切り替えシステムの安定性 一 固有值と動 作時間による安定条件; システム制御情報学会論文誌, Vol. 15, No. 5, pp. 232-237 (2002)

[5] 岩谷, 原: 固有值に着目した 2 モード区分的線形システム の安定解析 ; 計測自動制御学会論文集, Vol. 39, No. 11, pp. 1048-1053 (2003)

[6] 岩谷, 原: 固有值に着目した多モード区分的 2 次線形シス テムの安定解析; 第 46 回自動制御連合講演会資料 (2003)

[7] Y. Iwatani: Stability analysis and stabilization for hybrid control systems; 東京工業大学博士学位論文 (2004)

[8] 高橋: 力学と微分方程式, 岩波書店 (1996)

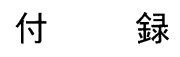

付録 1. 固有ベクトルの表現について

$A_{i}$ が 2 次の実数行列で, 仮定 1 が成り立つとき, $A_{i}$ の固有ベクトルは一般性を失うことなく,

$$
\left[\begin{array}{c}
1 \\
a_{i}+j b_{i}
\end{array}\right],\left[\begin{array}{c}
1 \\
a_{i}-j b_{i}
\end{array}\right], a_{i}, b_{i} \in \mathbb{R}, \quad b_{i} \neq 0
$$

と表すことができる。このことはつぎのように示される.

仮定 1 のもとでは $A_{i}$ の固有べクトルは複素べク トルとなり，それを $w_{i} \in \mathbb{C}^{2}$ とする。一般に固有べク トルはスカラ倍の自由度をもち, 任意の $c_{i} \in \mathbb{C} に$ 対 して, $c_{i} w_{i} \in \mathbb{C}^{2}$ も $A_{i}$ の固有ベクトルとなる。もし, $w_{i}=\left[\begin{array}{ll}w_{i 1} & w_{i 2}\end{array}\right]^{\mathrm{T}}$ における第一要素 $w_{i 1} \in \mathbb{C}$ が0 でない ならば（後でこのことは証明する）， $c_{i}$ を $1 / w_{i 1}$ とし た $c_{i} w_{i}$, すなわち, [ $\left.\begin{array}{ll}1 & w_{i 2} / w_{i 1}\end{array}\right]^{\mathrm{T}}$ も固有べクトルと なる．仮定 1 のもとでは， $A_{i}$ の 2 本の複素固有ベクト ルは互いに共役となる．したがって， $A_{i}$ の固有べクト ルが $\left[\begin{array}{ll}1 & w_{i 2} / w_{i 1}\end{array}\right]^{\mathrm{T}}$ と表されるとき，これにおける $w_{i 2} / w_{i 1} \in \mathbb{C}$ は $a_{i} \pm j b_{i}\left(a_{i}, b_{i} \in \mathbb{R}, b_{i} \neq 0\right)$ と表される.

ここで, $w_{i}=\left[\begin{array}{ll}w_{i 1} & w_{i 2}\end{array}\right]^{\mathrm{T}}$ における第一要素 $w_{i 1} \in \mathbb{C}$ が 0 でないことを示す.もし $w_{i 1}=0$ と仮定すると，

$$
\left[\begin{array}{ll}
a_{11} & a_{12} \\
a_{21} & a_{22}
\end{array}\right]\left[\begin{array}{c}
0 \\
w_{i 2}
\end{array}\right]=\lambda_{i}\left[\begin{array}{c}
0 \\
w_{i 2}
\end{array}\right]
$$

が成り立つ。ただし，

$$
\left[\begin{array}{ll}
a_{11} & a_{12} \\
a_{21} & a_{22}
\end{array}\right]=A_{i}
$$

であり, $\lambda_{i}$ は $\alpha_{i}+j \beta_{i}$ あるいは $\alpha_{i}-j \beta_{i}$ を表すとする. (A2) 式より,

$$
a_{22} w_{i 2}=\lambda_{i} w_{i 2}
$$

が得られる． $w_{i}$ は固有べクトルなので $w_{i} \neq 0$ であり, 仮定より $w_{i 1}=0$ なので, $w_{i 2} \neq 0$ である.これと $(\mathrm{A} 4)$ 式より

$$
a_{22}=\lambda_{i}
$$


となる. $A_{i}$ が実数行列のため左辺の $a_{22}$ は実数であり, 右辺 $\lambda_{i}$ の虚部 $\beta_{i}$ は 0 でないので, (A5) 式は矛盾して いる. したがって, $w_{i}=\left[\begin{array}{ll}w_{i 1} & w_{i 2}\end{array}\right]^{\mathrm{T}}$ に扔ける第一要素 $w_{i 1}$ は 0 とはならない.

\section{付録 2. 軌道の回転方向}

2.2 で述べた仮定 1 のように $A_{i}$ が複素固有值をもつ 場合, $\dot{x}(t)=A_{i} x(t)$ の軌道は渦状になる. サブシステム の軌道は領域 $\mathcal{S}_{i}$ 内のみで描かれるが, ここでは渦の回 転方向を考察するため, Fig.A1のように軌道を $x$ 平面 全域に拡張して, 初期値を $x(0)=[0, c]^{\mathrm{T}}, c \in \mathbb{R}_{+}$とす る.こ机に対する速度べクトル $\dot{x}(0) \in \mathbb{R}^{2}$ の方向を考え ると, その第一要素 $\dot{x}_{1}(0)$ の正負によって渦の回転方向 が決まる。ここではそれが $\beta_{i} / b_{i}$ の正負によって定まる ことを示す。

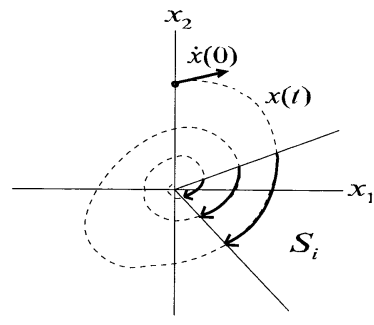

Fig. A1 Trajectory of $x(t)$

初期值に対するサブシステムの軌道 $x(t)$ は, $(12)$ 式, (16)式，(26) 式を用いることにより，

$$
\begin{aligned}
x(t)= & e^{A_{i} t} x(0) \\
= & T_{i} e^{\Gamma t} T_{i}^{-1} x(0) \\
= & {\left[\begin{array}{cc}
2 & 0 \\
2 a_{i} & 2 b_{i}
\end{array}\right] e^{\alpha_{i} t}\left[\begin{array}{cc}
\cos \beta_{i} t & \sin \beta_{i} t \\
-\sin \beta_{i} t & \cos \beta_{i} t
\end{array}\right] } \\
& \cdot\left[\begin{array}{cc}
2 & 0 \\
2 a_{i} & 2 b_{i}
\end{array}\right]^{-1}\left[\begin{array}{c}
0 \\
c
\end{array}\right] \\
= & \frac{c}{b_{i}}\left[\begin{array}{c}
e^{\alpha_{i} t} \sin \beta_{i} t \\
a_{i} e^{\alpha_{i} t} \sin \beta_{i} t+b_{i} e^{\alpha_{i} t} \cos \beta_{i} t
\end{array}\right]
\end{aligned}
$$

と計算される. 上式の第一要素を $t$ で微分すると,

$$
\dot{x}_{1}(t)=\frac{c}{b_{i}}\left(\alpha_{i} e^{\alpha_{i} t} \sin \beta t+e^{\alpha_{i} t} \beta_{i} \cos \beta_{i} t\right)
$$

となり, $t=0$ を代入すると

$$
\dot{x}_{1}(0)=\frac{c \beta_{i}}{b_{i}}
$$

となる. $c \in \mathbb{R}_{+}$なので, $\dot{x}_{1}(0)$ の符号は $\beta_{i} / b_{i}$ の正負で 決まる.そして $\beta_{i} / b_{i}$ が正のときには $\dot{x}_{1}(0)>0$ となり, $x(t)$ の軌道が描く渦は時計回りになる.

\section{付録 3. 補題 2 の証明}

$\Phi$ による変換は, $T_{N}^{-1} v_{1}$ 方向を向いたベクトル $\eta_{N}(t)$ を, 同方向で長さが $\rho$ 倍のベクトルに変換する.また, (29) 式において時間を表す $t_{i}(i=1, \cdots, N)$ に注目する と, 変換 $\Phi$ による経過時間は $(39)$ 式の $h$ であることが
わかる。したがって，

$$
\eta_{N}\left(t_{v_{1}}+h\right)=\rho \eta_{N}\left(t_{v_{1}}\right)
$$

が成り立つ.ただし $t_{v_{1}}$ は $\eta_{N}(t)$ が $T_{N}^{-1} v_{1}$ 方向を向い た時刻である。上式は

$$
\eta_{i-1}\left(t_{v_{i}}+h\right)=\rho \eta_{i-1}\left(t_{v_{i}}\right), \quad i=1, \cdots, N
$$

と一般化できる。ただし $t_{v_{i}}$ は， $\eta_{i-1}$ 平面において $\eta_{i-1}(t)$ が $T_{i-1}^{-1} v_{i}$ 方向を向く時刻である $(x$ 平面にお いて $x(t)$ が $v_{i}$ 方向を向く時刻でもある). (A10) 式が 成り立つことは, 定理 1 の証明の最初で初期值 $x(0)$ が 領域 $\mathcal{S}_{i-1}$ にあるとしても (37) 式と同じ式が導出され ることからわかる。(A10) 式で左から $T_{i-1}$ をかけると， (14)式より

$$
x\left(t_{v_{i}}+h\right)=\rho x\left(t_{v_{i}}\right), \quad i=1, \cdots, N
$$

となる. (A11) 式は $x$ が $v_{i}$ 方向を向いたときに成り立 つ関係式であるが，(A11) 式に扔ける $t_{v_{i}}$ をつぎに示す ように任意の $t \geq 0$ に拡張できる.

$t$ を任意のある時刻とし，そのときの $x(t)$ が領域 $\mathcal{S}_{i-1}$ にあり，それから時間 $t_{r}(\geq 0)$ だけ経過したら $x(t)$ が $v_{i}$ 方向を向くとし，そのときの時刻が $t_{v_{i}}$ であるとする (Fig.A2 参照)。すなわち，

$$
t_{v_{i}}=t+t_{r}
$$

と表されるとする， $t_{r}$ と（補題 1 での） $t_{i}$ の定義より,

$$
t_{r} \leq t_{i-1}
$$

が成り立つ。(A12)式より，

$$
x\left(t_{v_{i}}\right)=e^{A_{i-1} t_{r}} x(t)
$$

と表される。

ここで $x(t+h)$ について考える.(A12)式を用いると，

$$
x(t+h)=x\left(t_{v_{i}}+h-t_{r}\right)
$$

と表され，これは $x\left(t_{v_{i}}+h\right)$ を初期值として時間 $t_{r}$ だ け過去にさかのぼったときの解 $x$ の值に等しい，その初 期值 $x\left(t_{v_{i}}+h\right)$ は (A11) 式より $v_{i}$ 方向を向いているこ と, $t$ が増すときの $x(t)$ の軌道は時計回りであること, および時間 $t_{r}$ は $(\mathrm{A} 13)$ 式を満たすことから,$x\left(t_{v_{i}}+h\right)$

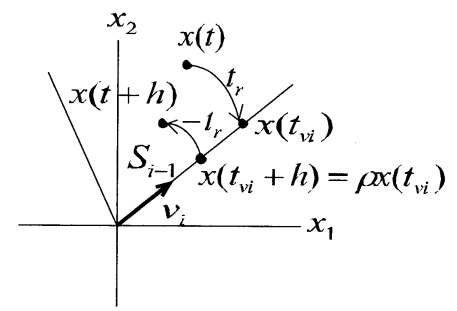

Fig. A2 Relation between $x(t)$ and $x(t+h)$ 
から $x\left(t_{v_{i}}+h-t_{r}\right)$ まで逆時間にさかのぼった軌道は領 域 $\mathcal{S}_{i-1}$ のみを通過する (Fig.A2 参照) 。したがって，

$$
x(t+h)=x\left(t_{v_{i}}+h-t_{r}\right)=e^{A_{i-1}\left(-t_{r}\right)} x\left(t_{v_{i}}+h\right)(\mathrm{A} 16)
$$

と表される。これに $(\mathrm{A} 11)$ 式を代入し，さらに(A14)式 を用いると，

$$
x(t+h)=\rho e^{A_{i-1}\left(-t_{r}\right)} x\left(t_{v_{i}}\right)=\rho x(t)
$$

が導かれる。

$t$ は任意であるので $(\mathrm{A} 17)$ 式において $t$ の代わりに $t+h$ を代入し，それに再び $(\mathrm{A} 17)$ 式を用いると

$$
x(t+2 h)=\rho x(t+h)=\rho^{2} x(t)
$$

が得られる。この繰返しにより(40)式が導かれる。

\section{付録 4. 定理 2 の証明}

任意の初期值に対する $(1)$ 式の解を $x(t)$ とし, $h, \mu$ をそれぞれ (39) 式，(42) 式で定義されるものとする. 区 間 $[0, h)$ に属する実数 $t_{p}$ をパラメータとした, 時刻 $t$ に対する指数関数 $\psi\left(t ; t_{p}\right)$ を

$$
\psi\left(t ; t_{p}\right) \triangleq\left\|x\left(t_{p}\right)\right\| e^{\mu t_{p}} \cdot e^{-\mu t}
$$

と定義する.また，パラメータ $t_{p} \in[0, h)$ でつくられる 指数関数 $\psi\left(t ; t_{p}\right)$ の集合を

$$
\Psi=\left\{\psi\left(t ; t_{p}\right) \mid t_{p} \in[0, h)\right\}
$$

と表すとする.

(A19) 式において $e^{-\mu t}$ にかかる係数 $\left\|x\left(t_{p}\right)\right\| e^{\mu t_{p}}$ に は, $t_{p} \in[0, h)$ に対する上限值と下限值が存在する。 そ れらを $(43),(44)$ 式で表せば, $\psi\left(t ; t_{p}\right) \in \Psi$ は

$$
\gamma_{\ell} e^{-\mu t} \leq \psi\left(t ; t_{p}\right) \leq \gamma_{u} e^{-\mu t}, \forall t \geq 0, \forall t_{p} \in[0, h)(\mathrm{A} 21)
$$

を満たす。

$(\mathrm{A} 21)$ 式までは $\psi\left(t ; t_{p}\right)$ を $t$ に対する指数関数とみな していたが,ここで, $\psi\left(t ; t_{p}\right)$ をある時刻 $t$ における関 数值とみなすことにする．そして， $t \in[0, h), k$ を任意 の非負の整数としたときの, 時刻 $t+k h$ における関数 值 $\psi\left(t+k h ; t_{p}\right)$ について考える. その值は, パラメー 夕 $t_{p} \in[0, h)$ を $t$ に等しくすると,

$$
\begin{aligned}
\psi(t+k h ; t) & =\|x(t)\| e^{\mu t} \cdot e^{-\mu(t+k h)} \\
& =\|x(t)\| e^{-\mu k h}
\end{aligned}
$$

となる.さらに $(42)$ 式より $e^{-\mu h}=\rho$ であること, およ び補題 2 より得られる

$$
\rho^{k}\|x(t)\|=\|x(t+k h)\|
$$

を用いると，(A22) 式は

$$
\begin{aligned}
\psi(t+k h ; t) & =\rho^{k}\|x(t)\| \\
& =\|x(t+k h)\|
\end{aligned}
$$

と変形できる．このように， $t_{p}=t$ としたときの関数值 $\psi\left(t+k h ; t_{p}\right)$ の值が $(\mathrm{A} 24)$ 式のように表されることは, つぎのことを意味する。間 $[0, h)$ に属する各 $t$ に対 して,

$$
\|x(t+k h)\|=\psi\left(t+k h ; t_{p}\right)
$$

を満たす $t_{p} \in[0, h)$ が存在する（各 $t$ に応じて $t_{p}=t$ と すればよい)。ここで

$$
\tilde{t} \triangleq t+k h
$$

とすれば， $t \in[0, h)$ より $\tilde{t} \in[k h,(k+1) h)$ となる.これ を用いると $(\mathrm{A} 25)$ 式は，区間 $\tilde{t} \in[k h,(k+1) h)$ に属する 各 $\tilde{t}$ に対して,

$$
\|x(\tilde{t})\|=\psi\left(\tilde{t} ; t_{p}\right)
$$

を満たす $t_{p} \in[0, h)$ が存在することを意味する（各 $\tilde{t}$ に応じて $t_{p}=\tilde{t}-k h$ とすればよい).すなわち, 区間 $[k h,(k+1) h)$ での各 $\tilde{t}$ に対する $\|x(\tilde{t})\|$ の值は, $\Psi$ に属 する指数関数 $\psi\left(t ; t_{p}\right) \quad$ (のいずれか) の $t=\tilde{t}$ における 関数值と一致する. このことと指数関数 $\psi\left(t ; t_{p}\right) \in \Psi$ が (A21) 式を満たすことより，

$$
\gamma_{\ell} e^{-\mu \tilde{t}} \leq\|x(\tilde{t})\| \leq \gamma_{u} e^{-\mu \tilde{t}}, \quad \forall \tilde{t} \in[k h,(k+1) h)(\mathrm{A} 28)
$$

が成り立つ. $k$ は任意の非負の整数なので, $k=0,1,2, \cdots$ とした (A28) 式をすべて合わせれば,

$$
\gamma_{\ell} e^{-\mu \tilde{t}} \leq\|x(\tilde{t})\| \leq \gamma_{u} e^{-\mu \tilde{t}}, \quad \forall \tilde{t} \geq 0
$$

が成り立つ.上式での記号 $\tilde{t}$ を $t$ と書き換えると (41) 式になる。 